\title{
A STRATEGIC FRAMEWORK TO UTILISE VENTURE CAPITAL FUNDING TO DEVELOP MANUFACTURING SMES IN SOUTH AFRICA
}

\author{
H. A. Snyman ${ }^{1}$, D. Kennon ${ }^{2}$, C.S. L. Schutte ${ }^{3 *} \&$ K. von Leipzig ${ }^{4}$ \\ Department of Industrial Engineering \\ Stellenbosch University, South Africa \\ ${ }^{1}$ hendriksnyman@sun.ac.za, ${ }^{2}$ dkennon@sun.ac.za, ${ }^{3}$ corne@sun.ac.za, ${ }^{4}$ kvl@sun.ac.za
}

\begin{abstract}
SMEs contribute considerably to the national GDP and to private sector employment, but they struggle to gain access to the funding needed to support business sustainability and growth. Venture capital provides the necessary funding, but SMEs lack understanding of the business value curve utilised by financiers to gauge the risk-reward characteristics of an investment. Strategies need to convey how the business model will evolve in order to deliver on the strategic intent. A framework is proposed through which SMEs can develop a strategy aligned with investor requirements. As a case study, the framework is applied to the local tooling sector.
\end{abstract}

\section{OPSOMMING}

SMEs dra betekenisvol by tot die nasionale BBP en werkskepping in die private sektor, maar SMEs sukkel om toegang te kry tot befondsing wat nodig is vir groei en volhoubaarheid. Waagkapitaal kan die nodige befondsing verskaf, maar SMEs benodig kennis van die besigheidswaarde kurwe, wat deur beleggers gebruik word om die risiko-opbrengs van ' $n$ belegging te assesseer. Strategieë moet oordra hoe die besigheidsmodel die strategiese intensie gaan aflewer. 'n Raamwerk word voorgestel waardeur die SME 'n strategie kan ontwikkel wat belyn is met die vereistes van beleggers. As gevallestudie word die raamwerk toegepas op die plaaslike gereedskap sektor.

Corresponding author

${ }^{1}$ Author was enrolled for a PhD (Industrial Engineering) degree in the Department of Industrial Engineering, University of Stellenbosch

2 Author was enrolled for a PhD (Industrial Engineering) degree in the Department of Industrial Engineering, University of Stellenbosch 


\section{$1 \quad$ INTRODUCTION}

Strategy is a critical component of business growth and success [1]. Current strategic models, however, are biased towards larger corporations [2]. Many entrepreneurs are not opting to formulate formal strategies [3], as current models neglect to detail the processes involved to guide the entrepreneur in such an endeavour [1].

A wide body of evidence supports the fact that SMEs are responsible for a considerable proportion of employment, contribution to the gross domestic product (GDP), and poverty alleviation in both developing and developed economies [4]. However, about $75 \%$ of new SMEs (small- to medium-sized enterprises) in South Africa do not become established; in fact, it is less likely that a new SME in South Africa will survive beyond 42 months than in any other Global Entrepreneurship Monitor (GEM) sampled country [5].

Although a host of models have been proposed to aid strategic development, these models do not detail the processes needed to develop the required strategies, nor do they take into account the specific characteristics and limitations of SMEs [2]. But this differentiation is vital, as small businesses are not just smaller versions of big businesses [1]: unlike their larger counterparts, smaller businesses have less formal planning, fewer control functions, simpler organisational structures, and less-developed administrative systems [2].

This paper refines the framework presented at the 2013 SAllE conference [6], with the addition of an illustrative case study, aimed at supporting SMEs in formulating a strategy. Unlike current strategic models, the framework presented here could act as a guide and detail the specific processes needed to arrive at an appropriate strategy that will enable SMEs to sustain their competitive advantage, and thus to grow.

\section{SOUTH AFRICA: SMES AND ECONOMIC GROWTH}

\subsection{Economic growth}

Economic growth theories were developed to explain the obvious differences in the development of productive capacities in different countries around the world. As such, they have some notable similarities to theories of business development.

Whereas traditional models ( [7], [8], [9] \& [10]) of economic development focused on increased output due to the accumulation of input factors (labour, capital, and natural resources) or efficiency gains (the result of education and technology), it is now widely accepted that entrepreneurship plays a critical role in long-term and sustained SME growth [9].

The Global Entrepreneurship Monitor (GEM) model, as proposed by Bosma et al. [11], classifies economic development into three stages according to the dominant drivers of increased economic output, along with the character of economic value-add. The model describes how economic development facilitates rising per capita income, and coincides with the migration of labour from the primary production and extractive services to manufacturing and later service industries, as illustrated in Figure 1. The model depicts the importance of the entrepreneur and ultimately the SME in each stage of these economies. 


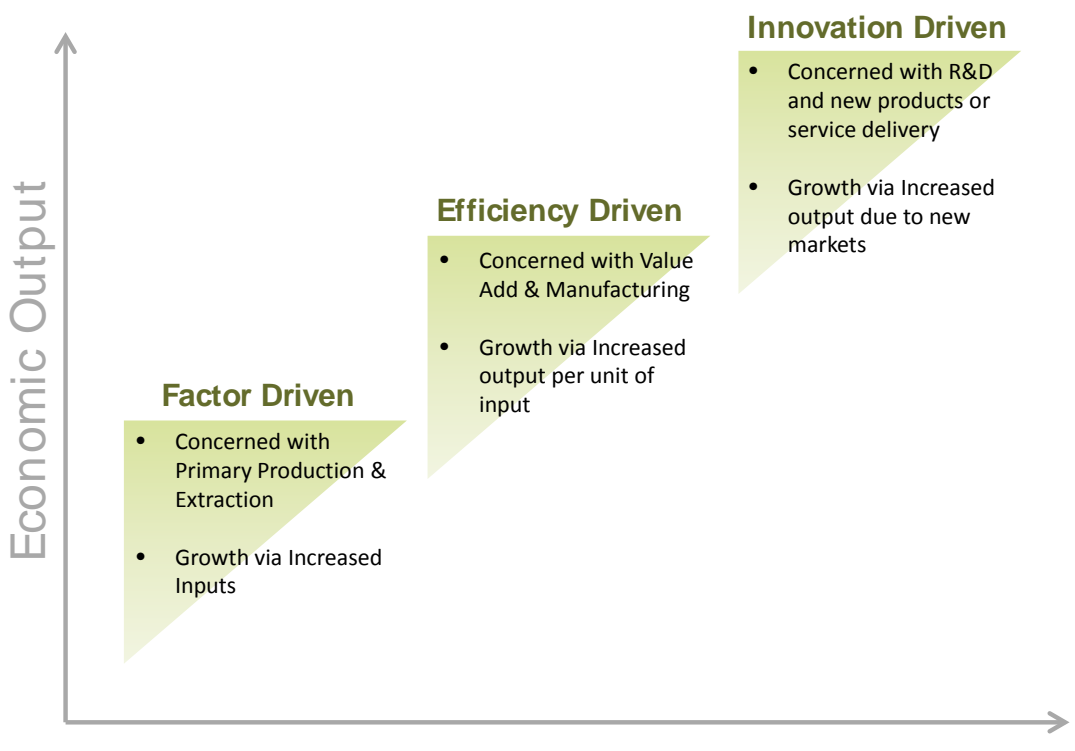

Time

Figure 1: The GEM Model (adapted from Bosma et al. [11])

Factor-driven economies are concerned with increased economic output associated with the primary production sectors, with supporting policies promoting growth through increased utilisation of input variables such as labour and natural resources, and also promoting foreign investment. Less developed countries often have a large agricultural sector, with the economic development of natural resources and the extractive industry promoting the migration of excess labour to these specific regions of economic activity. The resulting oversupply of labour in these regions results in surplus workers becoming entrepreneurs in an effort to create self-employment and thus to survive.

Efficiency-driven economies promote economic growth through processes that add value to primary production, increasing the value of economic output by absorbing a greater portion of the product value chain. As the value-adding industrial sector develops, small and medium enterprises emerge to support further industrialisation as they supply institutions that pursue increased production efficiency through economies of scale. These small and medium support companies are often the result of entrepreneurial actions as economic agents try to fulfill an industry need that is often initially met by imports.

Innovation-driven economies are synonymous with the development and delivery of new products and services. As the economy develops, an increase in disposable income translates into a shift from industrial activity to an expanding service sector to meet the needs of an increasingly affluent population. Increasing access to education translates into the industrial sector's ability to evolve and produce a larger variety and sophistication of products. As knowledge-generating institutions gather momentum, there is an increase in research and development, with opportunity-seeking entrepreneurs delivering innovative products and services, and even whole new industries. Subsequently these entrepreneurial businesses emerge as significant contributors to economic growth and to wealth creation.

It is important to note that entrepreneurship is not limited to small businesses: individuals in larger businesses can also undertake entrepreneurial activities. Drucker highlighted that these agents, the 'intrapreneurs', and larger businesses cannot survive "unless they acquire entrepreneurial competence" [12]. A significant portion of the literature in economics has stressed the importance of entrepreneurship at the micro-level to achieve economic growth at the macro-level (e.g. [13], [14] \& [15]). Consequently, Lumpkin and Dess [16] have 
touted the small business as an outstanding vehicle through which entrepreneurs can channel their entrepreneurial ambitions, as the business is seen as an extension of the individual who is in charge.

As Carlsson [17] noted, there is now a wealth of evidence that economic activity shifted from larger corporations to smaller businesses during the 1970s and $80 \mathrm{~s}$. The most often cited and most impressive example of this is the observation that the share of employment by the Fortune 500 companies dropped from 20 per cent in 1970 to 8.5 per cent in 1996.

Confronted with this evidence - as well as by rising concerns about unemployment, job creation, and economic growth - policy makers have responded by mandating and promoting new business creation and entrepreneurship [18].

\subsection{The SME: Survival \& growth}

Since the 1990s, research has been preoccupied with the importance of high-growth SMEs, arguing that a small number of high growth businesses are responsible for the majority of new jobs and most of the increased GDP output [19]. Together with this, an aversion (or inability) to achieve growth has been identified as a principal reason for business decline and ultimate failure [20].

In order to retain the socio-economic benefits of SMEs, these businesses ultimately have to survive in order to maintain "the continuity of business" [1]. Storey [19] proposes that growth is synonymous with longevity; negative or stagnant growth rates indicate future problems for the SME. Other motives for growth, along with continuity of business, include the achievement of economies of scale, increased market share and subsequent profitability, exploiting new business opportunities, credibility in the market, and achieving a higher market value for the business [19].

More recent research has revealed that growth is a multidimensional phenomenon, the result of both internal and external factors. Wiklund [21] proposed an integrative model (as illustrated in Figure 2) that suggests how entrepreneurial activity, the business environment, business resources, owner attitude towards growth, and strategic fit combine to create a sustainable competitive advantage.

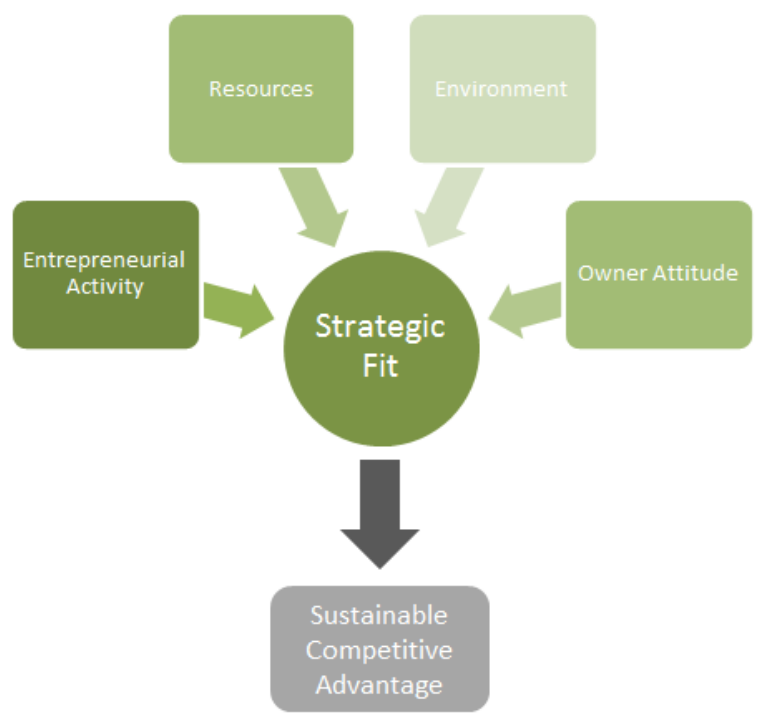

Figure 2: Business growth model adapted from Wiklund et al. [21]

Entrepreneurial activity in Figure 2 refers to a business's attitude towards innovation and risk-taking in delivering new products and services to a market; that is, it refers to how a 
business operates rather than what it does [21]. Several studies have shown that companies with an entrepreneurial culture experience sustained high growth rates and outperform their peers [22].

The environment relates to external factors that can be exploited to deliver performance. The environment has aggregate benefits for all market participants in that the business growth rate is affected by the industry growth rate [21]. However, studies have found that high growth among SMEs is due to their ability to develop market niches [23].

According to Wiklund [21], businesses have three distinct resources - physical, human, and network - at their disposal to deploy their strategy. The idea is that these resources have to be combined and utilised in a manner that creates a sustainable competitive advantage [24].

Owner attitude refers to the business owners' motive for starting and operating their business. Studies have shown that people have a variety of reasons for doing so beyond financial incentives [19]. Wiklund [25] proposed that - even if growth is not an entrepreneur's initial goal - business owners may develop a more positive attitude towards growth, especially if they are favourably exposed to the new tasks that accompany business growth.

Strategic fit refers to the business's ability to find a balance between these various factors and effectively compete in its market. Should a business be unable to acquire the necessary resources, or should it be ineffective in combining them to exploit a market segment, it will be unable to sustain a competitive advantage and will fail [21].

Academic studies suggest that business performance and growth is predominantly a function of an effective match between the various internal and external factors [1]; business growth rarely occur by chance, but rather arise from management's choices and subsequent conscious decisions. Weinzimmer [26] proposes that strategy is the most important determinant of growth.

\subsection{Strategy and growth}

There are a number of definitions of 'strategy'. However, it can be accurately described as "an overall collection of business decisions and actions" [27] in order to gain and sustain a competitive advantage. Hrebiniak and Joyce [28] maintained that a successful strategy enables business performance and effectiveness - the result of an effective match between the business, its processes, and the external environment.

The field of strategic management has been a popular topic for many decades, with seminal work being done by many experts. As a consequence different frameworks have been popularised by various pioneers in an effort to help businesses to exploit their strengths and weaknesses in relation to the external environment (Table 1).

Table 1: A collection of some of the more important strategic theories for this study

\begin{tabular}{|l|l|}
\hline Theory & Explanation \\
\hline Scenario planning & $\begin{array}{l}\text { Works by describing a small number of scenarios, by creating stories of how } \\
\text { the future may unfold, and how they might affect the issues that confront an } \\
\text { industry [29] \& [30]. }\end{array}$ \\
\hline Sensitivity analysis & $\begin{array}{l}\text { The study of the amount of variation found in the output of a mathematical } \\
\text { model due to the variability in the different sources of input into the model } \\
\text { [31]. }\end{array}$ \\
\hline Game theory & Allows the modelling of competitive interaction [31]. \\
\hline PESTE analysis & $\begin{array}{l}\text { Analysis of the environment in which an industry operates, using PESTE } \\
\text { (political, economic, social, technological and environmental) factors [31]. }\end{array}$ \\
\hline SWOT analysis & $\begin{array}{l}\text { Identifies the strengths, weaknesses, opportunities and threats of a } \\
\text { particular business [31]. }\end{array}$ \\
\hline Porter's 5 forces & Porter's competitive forces are used to analyse the attractiveness of an \\
\hline
\end{tabular}




\begin{tabular}{|c|c|}
\hline Theory & Explanation \\
\hline & industry structure [31] \& [32]. \\
\hline $\begin{array}{l}\text { Risk and } \\
\text { uncertainty } \\
\text { management }\end{array}$ & $\begin{array}{l}\text { Risk management strategies need to be tailored to the main characteristics of } \\
\text { the risk source in question [33]. } \\
\text { "Designers should deal with the upside of the probability distribution just as } \\
\text { they deal with the downside. They should build in the capability to deal with } \\
\text { these extraordinary circumstances. Dealing with both the upside and the } \\
\text { downside of uncertainties is not incompatible." [34] }\end{array}$ \\
\hline Open innovation & $\begin{array}{l}\text { "...systematically encouraging and exploring a wide range of internal and } \\
\text { external sources for innovation opportunities, consciously integrating that } \\
\text { exploration with business capabilities and resources, and broadly exploiting } \\
\text { those opportunities through multiple channels." [35] \& [36] }\end{array}$ \\
\hline $\begin{array}{l}\text { Blue ocean } \\
\text { strategy }\end{array}$ & $\begin{array}{l}\text { "Competing in overcrowded industries is no way to sustain high performance.; } \\
\text { The real opportunity is to create blue oceans of uncontested market space." } \\
\text { [37] }\end{array}$ \\
\hline $\begin{array}{l}\text { Diversification } \\
\text { strategy }\end{array}$ & $\begin{array}{l}\text { Diversification strategy is a business's focus on exploiting various industries } \\
\text { of operations [31]. }\end{array}$ \\
\hline
\end{tabular}

Whenever a business enterprise is established, it invariably employs a business model. Teece [38] described a business model as that which encapsulates the logic of how the company combines and utilises its resources to create and deliver value in order to deliver on its strategic obj ective.

Coupling competitive strategy analysis to business model design requires segmenting the market, creating a value proposition for each segment, and combining the resources to deliver value to the segment one is targeting. A good business model will provide considerable value to the customer and collect a viable portion of this in revenues. But developing a successful business model (no matter how novel) is not itself sufficient to assure a sustainable competitive advantage.

In order continually to deliver value to the customer and maintain a competitive advantage, the business has constantly to adapt the business model to the competitive environment by reviewing the combination of resources along with the structures for revenues and costs.

Once a business has established a competitive advantage, its growth strategy becomes critical for its survival and development [39]. Like economic development, businesses have the choice of being input factor driven (e.g. applying more capital, labour, and other resources to expand operations); efficiency driven (i.e. increasing output for the same input to grow market share); or innovation growth driven (e.g. launching new product or services). Companies can employ one or all of these strategies with varying degrees of success [40].

Integrating from above, businesses have three primary growth strategies at their disposal [40]: (1) a build strategy - i.e. vertical integration and absorbing more activities within the value chain; (2) an expand strategy - i.e. entering new markets or product segments; and (3) a maintain strategy - i.e. emphasis on market dominance through efficiency, innovation, and product differentiation within the current operating segment.

Within the expand and maintain strategies, Burns [41] proposes reviewing product/market strategies with options of (1) market penetration; (2) new product development; (3) new market development; and (4) moving into new markets with new products. Thompson [42] shows how these strategies can be realised through: (1) organic growth; (2) acquisition; (3) strategic alliance; and (4) joint venture. Given these available options, studies have produced mixed results, with theorists unable to agree on the best course of action to accelerate growth [1].

Nooteboom [43] argued that a successful growth strategy would take into account the business-specific characteristics related to the size of the business as well as the interacting internal and external factors. The different decisions and actions would thus 
follow and hold under different conditions, given a set of entrepreneurial characteristics that might be beneficial in one configuration or context and action might work adversely in another.

Although the strategic frameworks and growth strategies mentioned here have been widely accepted and successfully applied in industry, they do not take into account the specific characteristics of small businesses, and have been biased towards larger, more established corporations [1]. It is important to take into account the specific dimension of SMEs, as small businesses are not just smaller versions of big businesses (as discussed earlier).

Smaller businesses within an industry require distinctly different strategies than their larger counterparts. The critical requirement for small businesses in these industries is strategic flexibility [44]. These businesses have to be more flexible, have closer ties with their customers, and have the ability to translate their vision into action more efficiently [45].

Smaller companies, generally, are the result of an entrepreneur's initiatives with less formal planning and fewer control functions, together with a lack of organisational and administrative systems [1]. These small businesses also struggle with limited financial, technological and human resources, little market information, and necessary economies of scale [45].

Although small businesses have numerous advantages over their developed counterparts, their ability and will to develop a business strategy is influenced by entrepreneurial motivation and competency [2]. Unless business owners have a strong belief in their ability to formulate a successful strategy and to grow the business, they would not attempt formal strategy formulation but rather align their goals along a certain objective.

In an entrepreneurial organisation strategic intent, strategic ambitions, and concentration on the actions that achieve the business's objective [46] provide emotional and intellectual energy. Strategic intent is the antithesis of strategy focus, which attempts to search for a fit between existing resources and emerging opportunities, whereas strategic intent stipulates an aspirational outcome, recognises the misfit between resources and aspirations, and attempts to find a way to bridge the gap. It provides a sense of direction and purpose for each stakeholder in the organisation [47] \& [25].

Interviews with the founders of 100 major companies in the USA showed that the entrepreneurs behind high-performing companies adopt strategic intent as a faster and cheaper method of strategy planning [48]. These entrepreneurs integrate action and analysis, and emphasise the need for strategic orientation in management and for knowledge about the market, customers and competitors in a global environment of increasing competition and shortening product and service life-cycles.

A study on the growth of small and medium manufacturing businesses showed that successful businesses exercised financial control and monitored key variables that related to the strategic objectives of the company [49].

\subsection{Barriers to growth}

Even with the recognition that SMEs are vital to stimulating entrepreneurship and thus economic growth, a number of obstacles inhibit them from realising their full potential: lack of access to managerial skills, finance, equipment, technology, and networks and international markets; and regulatory issues [50].

The regulatory environment plays a critical role in the establishment and operation of a small business [51].

- Regulations can both help and hinder entrepreneurs.

- $\quad$ Entrepreneurs need clear rules that are predictably enforced. 
- Over-regulation can impose burdens on all businesses, and can thus be viewed as a prohibitive start-up cost.

Similarly, managerial competencies are fundamental to SME development. Martin and Staines [52] proposed that a lack of managerial competency is the main reason that new businesses fail. The lack of support services, or their relatively higher unit cost, was also found to hamper SMEs' efforts to improve their management capabilities. This is because consulting businesses are often not equipped with appropriate cost-effective management solutions for SMEs. This is supported by evidence [53] that, although numerous institutions provide training and advisory services, there is still a skills gap in the SME sector as a whole due to the inability of many entrepreneurs to afford such services.

Networking has also been established as critical to SME development, as this can both boost performance and increase access to finance, expertise, markets, and collaborative partners [54]. Shane and Cable [55] concluded that networking reduces information asymmetry in negotiations with creditor, debtors and other financiers. Ngoc et al. [56] point out that "in the absence of effective market institutions, networks play an important role in spreading knowledge about a business' existence and its practices".

Investment in up-to-date technology is increasingly important to all businesses, not only start-ups and SMEs. Technology supports entrepreneurs in the implementation of their strategy by maximising business opportunities [57]. However, the use of technology also involves costs; and where new or even established SMEs experience difficulty in purchasing the necessary technology, this may hamper their growth and sustainability [58].

Another important problem that SMEs often face is access to capital [59]; such a lack of access or availability can be a practical constraint on business growth [60]. Cook and Nixson [61] concluded that "notwithstanding the recognition of the role of SMEs in the development process in many developing countries, SME development is always constrained by the limited availability of financial resources to meet a variety of operational and investment needs".

Although a host of strategic models have been proposed to aid strategic development, these models do not detail the processes needed to develop the related strategies, nor do they take into account the specific characteristics and limitations of SMEs [1].

\section{THE ROLE OF VENTURE CAPITAL IN SMES}

In his 2007 study, Thomas Dickinson [62] proposed that private equity can serve a useful role in addressing many of the shortcomings of SMEs. Private equity fills the gap between entrepreneurs financing the business themselves and conventional capital market activity in growing private enterprises.

Private equity can, through its investment in local businesses, play a catalytic role more efficiently than other forms of external investment, where non-financial contributions are not guaranteed. The impact that private equity has had on business development extends beyond the financial backing to the contribution of business expertise, training, networks, and skills transfer, all of which would raise the efficiency of the sector being entered [62].

\subsection{Venture capital}

Venture capital (VC) investments are private, non-exchange-traded equity investments in a business venture. Due to the higher risk of the investment, investors expect a higher rate of return compared with exchange-traded equities. The investments may be made at any point of the business cycle of the company, from the initial planning stages of a new venture to an established firm ready to go public [63].

How VC is defined differs between countries: some include 'angel financing' (an investor who provides funding for start-ups and entrepreneurs) in VC, while in other countries VC 
stretches to right before the maturity phase, as illustrated in Figure 3. The present authors assume that VC financing reaches into early stage expansion, with the rest of the private equity phases continuing from late stage expansion. Assuming this definition of VC does not change the functionality of other phases found in other areas of literature.

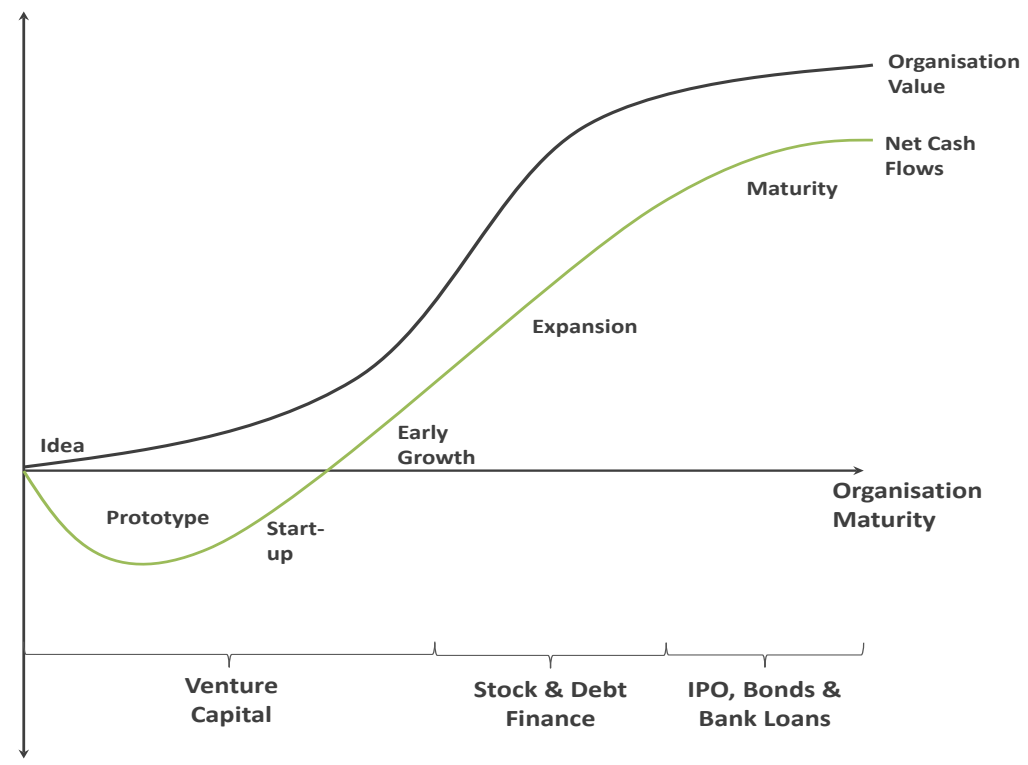

Figure 3: J-Curve: The business cycle and the financial demands per stage, adapted from Meyer and Mathonet [64] and Cui et al. [65]

In South Africa, the value of private equity financing that flowed into SMEs in 2010 was less than R400 million $(0.014 \%$ of SA'S GDP) [66]; but this is expected to increase with the implementation of Regulation 28. Regulation $28^{\prime} \mathrm{s}$ aim is to ensure that the savings that South Africans contribute toward their retirement are invested in a prudent manner - one that not only protects the retirement fund member, but is also channelled in ways that would achieve economic development and growth. The portfolio composition is required to comply with the asset limits of Regulation 28 [67]. The alternative investments limit, which increased to $15 \%$ of the portfolio's limit, includes hedge funds, private equity funds, and other assets, as shown in Table 2. The increase in this limit is expected to increase the amount of funds available to private equity and VC funds.

Table 2: Alternative investments according to Regulation 28 (adapted from Old Mutual [67])

\begin{tabular}{|c|c|c|}
\hline Asset sub-category & Total limit & Per issuer \\
\hline \multicolumn{3}{|c|}{ Alternative investments - up to $15 \%$} \\
\hline Hedge funds & $10 \%$ & $\begin{array}{l}\text { Fund of hedge funds - } 5 \% \\
\text { Hedge funds }-2.5 \%\end{array}$ \\
\hline Private equity funds & $10 \%$ & $\begin{array}{l}\text { Fund of private equity funds - } 5 \% \\
\text { Private equity funds }-2.5 \%\end{array}$ \\
\hline $\begin{array}{l}\text { Other assets not referred } \\
\text { to in this schedule } \\
\text { (excluding hedge or } \\
\text { private equity funds) }\end{array}$ & $5 \%$ & $2.5 \%$ \\
\hline
\end{tabular}

\subsection{The Venture capital process}

The success of an investment with a portfolio of investments for private equity (including VC) companies would be managed through the active management of this portfolio of companies and the timing and size of exits. This is accomplished through [64]: 
1. Pooling capital in order to invest in private companies (this gives smaller investors access to private companies experiencing greater growth than their publicly-traded peers);

2. The delegation of investments through fund managers with the required experience and incentives to screen, evaluate, and select businesses with potential for high growth; and

3. The fund managers source exit opportunities and realise their gains by exiting businesses and subsequently realising a return from the portfolio of businesses for the private equity fund's investors.

In order for an investment to be exit-able, a suitable buyer needs to be found. This can be done in a number of ways, of which the main strategies include a private sale or an Initial Private Offering (IPO). The business would thus need to be driven up the J-curve towards a purchasable business or one that can be offered publicly (Figure 3). In order for this growth to happen, the business would need to pass through or skip various stages of business development in order to have grown. During initial assessments for investment, the business will be subjected to assessments that evaluate whether it will be able to survive through the various developmental phases to the point where it is exit-able.

The businesses in which VC companies normally invest generally have high growth potential [68], highly-educated and experienced managers [69], a good level of intellectual property, pursue high growth [70], and have either a higher innovative output [70] or a high level of research and development $(R \& D)$ spending and the presence of $R \& D$ employees.

VC is driven by innovation [68], but for smaller businesses innovation's scalability is not as quick as investors would like it to be. The risks in a business change as it moves from startup to expansion. The initial risk in a start-up is predominantly the product risk (whether a product/service will be adopted), which then shifts to whether the business is scalable or vertically integratable (able to acquire parts of the value chain to increase business value), collectively known as 'expandability risk'.

The common investor assessment stages found in early stage financing (Figure 4) describe how a business is initially evaluated based on tangible, objective criteria; but this changes to a less tangible, more subjective dimension that is more observable in the entrepreneur's presentation. Team size or experience is less important in the later assessment stages than the significance of the entrepreneurs' social skills, such as impression management, persuasiveness, ability to think on their feet, and to answer questions and advise over measurable factors [72].

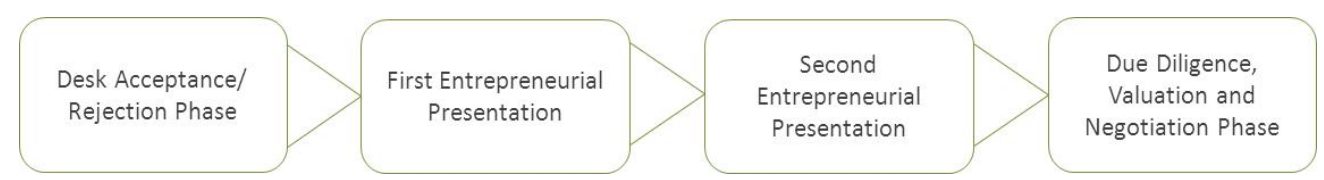

Figure 4: Common investor assessment stages of a business (adapted from [72])

In the end, the investor's view (whether or not it is influenced by the entrepreneur) determines investment readiness, based on the business's team, its operations, customer base, skills and competencies, and its potential to scale; and these are weighed against investment risks and returns and time to exit [73] \& [74].

The most important differences in the perceptions of investment readiness can be summed up in the following points [72]:

- $\quad$ They must have some form of intellectual property;

- They require a fully formed management team with experience;

- They should have a product/ service in the advanced stages of development; and

- They should have some established customer base. 
These differences need to be addressed by the entrepreneur to ensure that the probability of success in applying for funding is increased.

\subsection{The venture capital valuation process}

The difficulty for venture capitalists is the complication in the valuation process in an entity where the price is not defined by a market, but through financial considerations that play only a small part alongside other considerations, such as the industry characteristics (structure, trends and markets) and the business's characteristics (development stage, competitiveness, etc) [75]. Mainstream finance theory measures the economic value of any investment through the present value of future cash flow; but this presents some difficulties when applied to businesses in the early stage of their development, as most information is not available to deliver on this calculation. This has often been the source of frustration between VCs and entrepreneurs; yet entrepreneurs can set up their businesses in a way which would result in higher valuations by VCs [75].

Research on VC valuation methods has highlighted the main factors that are taken into consideration when determining the value of a business [75]:

\section{Top management and the entrepreneur (arguably the most important)}

The business is valued significantly higher if top management has the relevant industry experience, and relevant managerial and start-up experience prior to playing a role in the current business. The spread of skills in top management also reduces the 'key man' dependency risk (risk of losing an individual who holds all the knowledge).

\section{Differentiated industries}

Businesses that operate in highly-differentiated industries with positive industry growth add to their pre-money valuation (value of business before it goes public).

\section{Networks}

There is a high correlation between the size of a network and the valuation made by the VC company. The role of alliances and innovation capability positively influences the business' $s$ performance and the VC company's perception of it. The quantity and quality of these networks are salient signals to the VC firm that positively correlate with the speed and valuation of an IPO.

The criteria that can be addressed to increase the value of the business are found to be negatively correlated with the business's risk; and this highlights a higher probability of success for the business. The probability of success is also increased by the non-financial contributions of VC companies to the businesses.

\subsection{Non-financial venture capital contributions}

Once the VC has selected a business as worthy of investment, it will provide the business with the funding and coaching it needs to develop its potential. VC companies that provide support for their investments see better performance and a more substantial return-oninvestment [76] \& [77].

VC companies' exposure to a large number of businesses builds the necessary experience, resulting in an in-depth knowledge of the elements required at each stage of business development [77]. This experience, together with an extensive network of contacts, is crucial when deciding on an investment and on the appropriate resources and configuration needed to grow the business.

A summary of the non-financial contributions from VC companies is given in Table 3.

Table 3: The non-financial contribution of VC firms [77], [75], [73], [72], [74]\& [78]

\begin{tabular}{|l|l|}
\hline Contribution & Explanation \\
\hline Entrepreneur & The VC company's role in coaching and obtaining buy-in from the entrepreneur \\
\hline
\end{tabular}




\begin{tabular}{|l|l|}
\hline Contribution & Explanation \\
\hline $\begin{array}{l}\text { and top } \\
\text { management }\end{array}$ & and top management regarding the strategy and operation of the business. \\
\hline $\begin{array}{l}\text { Industry } \\
\text { structure }\end{array}$ & $\begin{array}{l}\text { The VC company leverages off its current resources in order to test future } \\
\text { products and services in the market, evaluate customer needs, understand } \\
\text { possible untapped markets, and connections within the industry. }\end{array}$ \\
\hline $\begin{array}{l}\text { Organisational } \\
\text { structure }\end{array}$ & $\begin{array}{l}\text { A business's ability to innovate, as well as the human resources management } \\
\text { practices, form an important part of the resource-based view, which } \\
\text { acknowledges the organisation's resources as important for its competitive } \\
\text { advantage. }\end{array}$ \\
\hline \multicolumn{1}{|c|}{$\begin{array}{l}\text { Innovation } \\
\text { capability }\end{array}$} & $\begin{array}{l}\text { VC companies facilitate social ties with economic partners, supporting an } \\
\text { organisation's collaborative innovation capabilities. These ties lead to knowledge } \\
\text { transfer, reducing the product development period and time to market. }\end{array}$ \\
\hline $\begin{array}{l}\text { Hesources } \\
\text { Manageme } \\
\text { nt (HRM) } \\
\text { capability }\end{array}$ & $\begin{array}{l}\text { The HRM practices and employee retention are improved through the VC } \\
\text { company's tacit knowledge (rewards systems, and policies for recruitment, } \\
\text { evaluation and performance), reducing HRM issues and thus increasing the } \\
\text { business's probability of success. }\end{array}$ \\
\hline $\begin{array}{l}\text { Networks } \\
\text { DC companies use their networking capabilities to draw on the collaborative } \\
\text { resources and expertise of a network. The networking capability adds a level of } \\
\text { legitimacy, allowing businesses to obtain resources that would otherwise have } \\
\text { been unavailable. }\end{array}$ \\
\hline
\end{tabular}

A business's strategic readiness is one of the highlighted cogs that are assessed when it applies for financing. This preparedness of a business's people, systems and structure to deliver on its strategy is defined by the human, information and organisational capital - the intangible assets that are the foundation for strategic change, which most often involves new markets, products, or corporate transformation [79].

\section{A PROPOSED STRATEGIC FRAMEWORK FOR DEVELOPING SMES}

Models are used to develop theories by isolating and studying a few key input and output variables under situation-specific conditions [80]. These models usually are rigorous and have limited complexity, with their relevance being a function of fit between their assumptions and reality. In strategy, no one model can embody all the relevant variables, and thus the applicability of any model' $s$ findings are almost inevitably restricted to a small group of businesses or industries whose characteristics fit the model's assumptions.

In contrast, a framework encompasses many variables and seeks to capture as much of the complexity of practical situations as possible. The framework provides the necessary variables and the questions users must answer in an attempt to guide them to develop conclusions that are tailored to an industry and/or an organisation [80]. The theory embodied in frameworks is contained in the choice of included variables, the way variables are organised, the interactions among the variables, and the way in which alternative patterns of variables and company choices affect outcomes.

A framework allows for the fact that not all the interactions among variables can be rigorously described. The framework seeks to help the analyst to analyse the problem better through understanding the business and its environment, and defining and selecting from among the strategic alternatives available, no matter the industry or starting position.

Based on this thought process, a framework is used to build on the variables that are generated and proven by more simplistic situation specific models. 


\subsection{Systems engineering approach to problem-solving}

The systems engineering approach to solving complex problems is to deconstruct the problem into functional units, finding a solution for each problem, reviewing the interaction of the various solutions, and where necessary finding new solutions, so that the reconstructed holistic system may be the most efficient recombination of the various individual solutions [81].

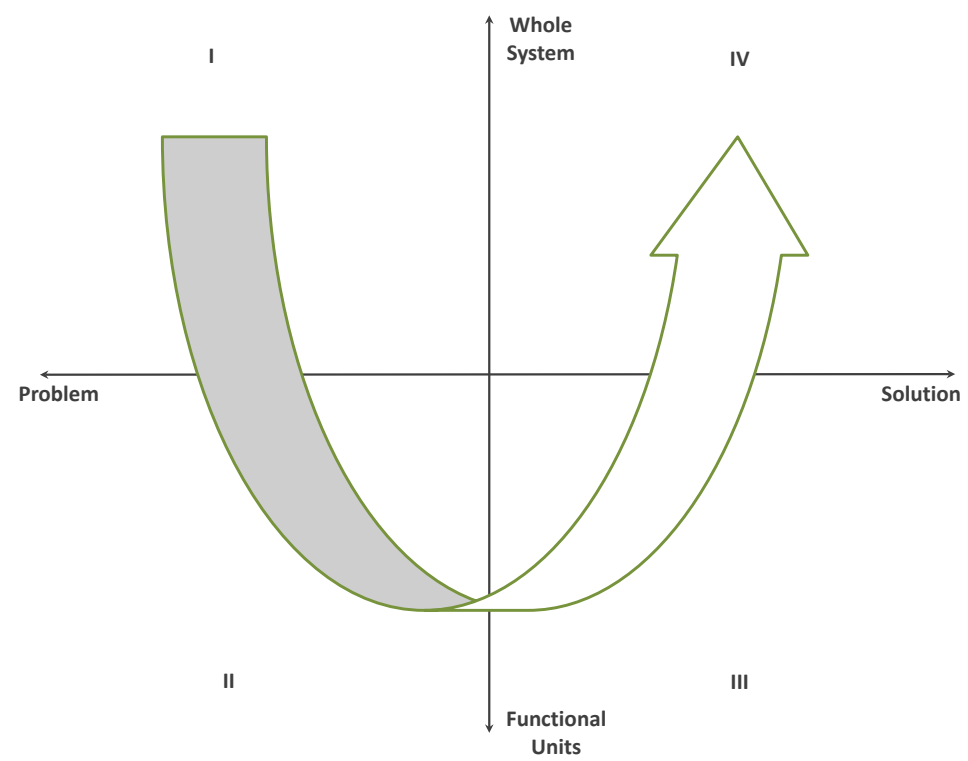

Figure 5: Flow of real world problem-solving (adapted from [81])

Figure 5 illustrates this approach. A system problem might be complex as a whole (I), but it needs to be broken down into smaller sub-problems (II). It is in the second quadrant that a greater understanding of the source of the individual issues is unearthed. A large number of sub-solutions can be found for the sub-problems (III), which can then be pieced together to find a solution for the whole (IV).

An important part of a systems approach to problem-solving is to ensure that the desired objective of the system is reached. One way to ensure this is through built-in feedback systems. In the real world flow of problem-solving, this feedback system would be embedded between each of the quadrants.

\subsection{Strategic venture architecture framework}

The proposed strategic venture architecture (SVA) framework utilises the systems engineering approach to guide entrepreneurs through specific processes in order to formulate a tailored strategy and business model for their industry and environment.

Through the research on common growth barriers for SMEs, the role of VC, strategic formulation, and the system's engineering approach, the SVA framework guides the entrepreneur and SME management team to develop a successful value proposition, business model, and strategy in order to align the SME with the value curve and thus attain the necessary funding and VC expertise to grow the business.

The SVA framework (Figure 6) uses the same flow of information as detailed in Figure 2, and utilises proven tools and models to guide the entrepreneur or SME management to answer the relevant questions posed at each stage. The tools given in Figure 6 might be old or new, and are not the only tools available; but they have been used according to what the authors believe is applicable. These tools are given here to guide the entrepreneur to utilise them in a different way to reach the desired objectives per quadrant. The tools are 
not the only ones applicable to the task at hand: the framework is alive, and so no exact recipe should dictate how strategists reach the deliverables.

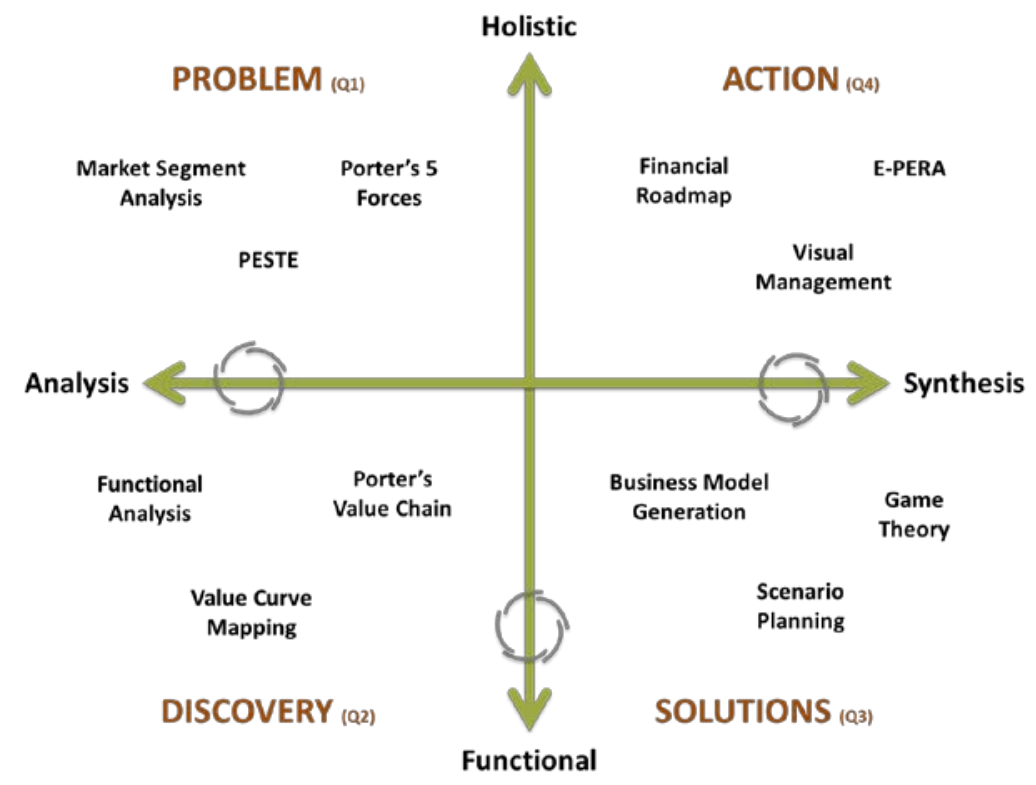

Figure 6: The Venture Architecture Framework

The $\mathbf{1}^{\text {st }}$ quadrant (Q1) begins where every endeavour should start, by analysing the external market conditions. The tools prescribed for the entrepreneur or SME management should provide them with insight into the following issues (possible applicable tool(s) provided in brackets):

- What are the future industry trends (PESTE)?

- What is the current industry structure (Porter's Five Forces)?

- How is the industry currently delivering value to the various market segments (Market Segmentation)?

The objective of the quadrant is to:

- Identify a displacement between segment needs and current offerings in the market (Blue Ocean Strategy).

The $\mathbf{2}^{\text {nd }}$ quadrant (Q2) applies functional analysis to deconstruct Porter's value chain and value system [80] to identify the critical system, technology and resource elements used to perform the business functions that drive a business up the J curve to deliver value to the customer segment. This is conducted along the various stages of the value curve, called here 'value curve mapping', in order for the entrepreneur or SME management to answer the question:

- How are industry participants currently combining the various elements within the business function to deliver value to the customer?

The $3^{\text {rd }}$ quadrant (Q3) seeks to formulate a business model as a way for the business to fulfill its strategic intent to deliver true value to a displaced customers segment (question asked in Q1). Utilising the knowledge of the elements that are able to perform the various business functions, the business model should combine business elements that efficienctly and effectively deliver value to the customer together with various isolating mechanisms that would prevent the business strategy from being undermined by imitation by competitors or disintermediation by customers [38].

Deciding on a growth strategy to best deploy the business model, the $\mathbf{4}^{\text {th }}$ quadrant (Q4) aims to guide the entrepreneur to define how capital will be utilised to effect business 
growth through one or all of the following growth strategies: vertical integration, efficiency, or expansion by means of a financial roadmap. By using the E-PERA framework [82], the entrepreneur or SME management would have to define the systems and procedures to plan, co-ordinate and control the various business functions. By designing and implementing a visual management system, the business will have created a structured communication system and made knowledge more explicit and less tacit. The quadrant aims to address risk related to growth by providing the necessary structure and clarity on the way forward [45].

The role of feedback in Figure 6 can be found between each quadrant, highlighting the fact that, as Eric Sevareid (a well-known journalist in the USA) puts it: "The chief cause of problems is solutions". Every model, plan, mitigation strategy, etc. needs to be tested to ensure that it still fulfills its role without being the cause of larger problems. This framework will be notably less effective without feedback between all quadrants.

\section{CASE STUDY: DEVELOPMENT OF A TOOLING CLUSTER}

In an industry where local tool manufacturers were able to provide the necessary support for the local manufacturing industry, their inability or unwillingness to adopt the necessary systems, techniques and technology to remain current has resulted in the degradation of their market share from 90\% in 1990 to less than $15 \%$ in 2012 [83].

The SVA framework was applied to the tooling industry to formulate a business model for the National Tooling Initiative (NTI), a national programme that trains young apprentices to become tool makers in an effort to improve the local tooling industry. The proposed business model would have to deliver value to the industry and address misconceptions regarding South Africa's ability to deliver effective quality tools.

\subsection{Q1 - Market research}

Applying the various tools prescribed in Q1 of the SVA framework, the market segmentation shown in Figure 7 below was revealed, along with particular insights into the market structure.

A common element in all the market segments was that local manufacturers' inability to adopt modern manufacturing and project management techniques meant that local suppliers had gained the reputation of not delivering the required goods on time, and thus forcing local customers to seek international suppliers.

Porter's Five Forces analysis revealed that the base segment was susceptible to new market entrants, with participants competing on price to deliver lower complexity tools with less stringent tolerance specifications. The mid-technology segment is more difficult to infiltrate as suppliers need to generate trust in delivering tools that can perform more complex functions along with after-sale maintenance services. The premium segment is the most difficult to supply, with participants competing with the ability to provide efficient tools with demanding tolerance specifications.

Numerous value displacements are evident within the industry. For the lower segment, Asian and East European imports often arrive and require modifications because of ineffective specification translations. Local companies are unable to provide the necessary after-sale services for the medium technology segment imports: they are unfamiliar with the tool function through lack of insight into the motives behind the design. With superior tool design capabilities, West European tool manufacturers face considerable barriers to entry; however, local customers have to pay significant fees to import large complex tools with associated shipping lead times, and to ship them back to the country of origin for maintenance and repairs. 


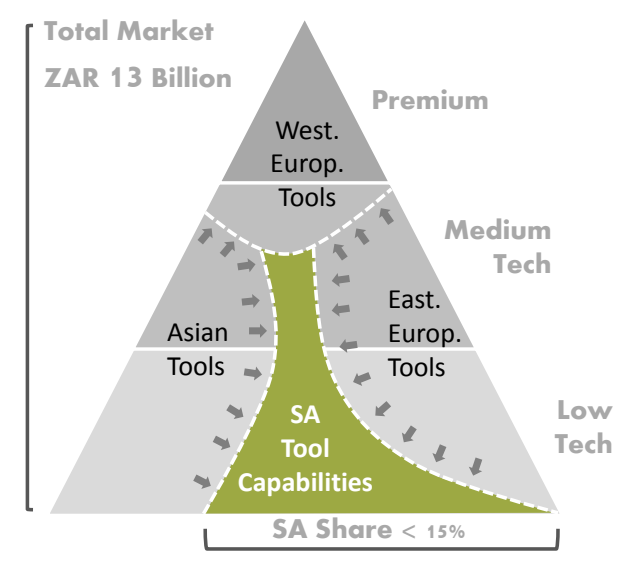

Figure 7: South African tooling industry market segmentation

\subsection{Q2 - Functional analysis}

Figure 8 illustrates the critical business functions employed to deliver value to the customer at the various stages of development.

\begin{tabular}{|c|c|c|c|c|}
\hline Business Element & $\begin{array}{l}\text { Small Scale } \\
\text { Competitors } \\
\end{array}$ & $\leftarrow$ & $\Rightarrow$ & $\begin{array}{c}\text { Mature } \\
\text { Competitors } \\
\end{array}$ \\
\hline Technology & $\begin{array}{l}\text { - Trying to make } \\
\text { do with outdated } \\
\text { technology, } \\
\text { depending on } \\
\text { operator abilities }\end{array}$ & 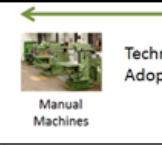 & $\begin{array}{c}\text { Inology } \\
\text { ption } \\
\substack{\text { HSC S Avis } \\
\text { Milling }}\end{array}$ & $\begin{array}{l}\text { - Latest } \\
\text { technology to } \\
\text { improve speed } \\
\text { and accuracy, } \\
\text { capabilties and } \\
\text { client offering }\end{array}$ \\
\hline Software & $\begin{array}{c}-2 D \text { and } 3 D \text { CAD } \\
\text { Software }\end{array}$ & $\begin{array}{l}\text {-3D CAD Software } \\
\text { - CAM Software }\end{array}$ & $\begin{array}{c}\text { - Latest CAD/CAM } \\
\text {-Tool } \\
\text { Manufacturing } \\
\text { Simulation }\end{array}$ & $\begin{array}{l}\text { - Latest CAD/CAM } \\
\text { - Tool \& Product } \\
\text { Manufacturing \& } \\
\text { Simulation } \\
\text { - Force Simulation }\end{array}$ \\
\hline Service Offering & $\begin{array}{l}\text {-Tool Production } \\
\text { from Technical } \\
\text { Drawing Supplied } \\
\text { by Customer }\end{array}$ & $\begin{array}{l}\text { - Limited Tool } \\
\text { Design from } \\
\text { Product Drawings } \\
\text {-Tool Production }\end{array}$ & $\begin{array}{c}\text {-Limited Product } \\
\text { Design } \\
\text { - Tool Design } \\
\text {-Tool Production } \\
\text {-Tool } \\
\text { Maintenance }\end{array}$ & $\begin{array}{l}\text { - Holistic Solution } \\
\text { from product } \\
\text { design, } \\
\text { prototyping, } \\
\text { manufacturing } \\
\text { automation and } \\
\text { maintenance }\end{array}$ \\
\hline Management Style & $\begin{array}{l}\text { - Artisinal } \\
\text { Approach }\end{array}$ & $\sqrt{6+5} 6$ & 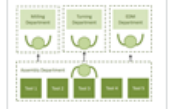 & $\begin{array}{l}\text { - Industrial } \\
\text { Manufacturing } \\
\text { Approach }\end{array}$ \\
\hline Capabilties & Low Tech & Low/Medium Tech & Medium/High Tech & $\begin{array}{l}\text { High Tech \& } \\
\text { Premium Tooling }\end{array}$ \\
\hline Customers & Local $\leftarrow$ & $\begin{array}{l}\text { - Many clients } \\
\text { from Quatation } \\
\text { Approach }\end{array}$ & $\begin{array}{c}\text { - Limited Repeat } \\
\text { Customers from } \\
\text { Strategic \& Equity } \\
\text { Partners }\end{array}$ & Global \\
\hline
\end{tabular}

Figure 8: Functional analysis of business functions of tooling suppliers

With the insights provided above, a strategic intent was formulated that declared that a successful business should deliver tool design and manufacturing services to the middle and premium market segments, where the industry structure would provide shelter from competition, should the business model be able effectively to deliver value to the customer.

From the value curve, it was evident that smaller scale businesses would need to address the following mis-fits to drive them up the value curve: 
- Design capability - South Africa's lack of experience within the medium and premium tooling segments means that local smaller businesses do not have design experience for those respective segments.

- Economies of scale - The size of lower value curve entrants results in lower utilisation of software and hardware resources, forcing businesses to utilise resources with limited manufacturing and design capability, and thus preventing them from servicing the middle and premium tech segments.

- Economies of scope - With the economics of the industry and business requiring high business infrastructure utilisation rates, smaller companies cannot conduct final tool testing, as the machine used for the manufacturing process of the final product would remain idle for long periods, owing to the lower throughput of smaller businesses.

- Financial resources - Even if a smaller company were able to deliver the required service to the middle or high tech income segments, the company's limited working capital would prohibit them from tendering the service, given the relatively higher cost of the product and the associated production lead time.

\subsection{Q3 - Business model generation}

A business model was designed by reconfiguring the elements within the various business functions, providing a central channel for design, importing and manufacturing services.

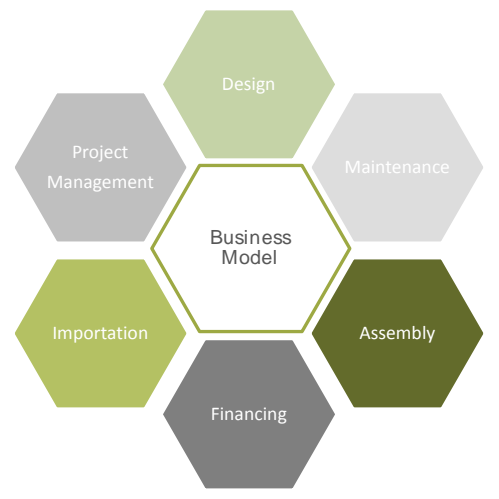

Figure 9: Business model components

- $\quad$ The business model hinges on the company's ability to design medium and premium tooling. The value curve mis-fit was bridged by partnering with a German company to provide the initial concept design (a source of their technical expertise), allowing local designers to conduct the more detailed design with periodic internet-based design reviews.

- $\quad$ The company would fulfill a project management role, outsourcing the manufacturing process to local or international companies whose technological capability to produce the tooling was vetted to ensure that they employed the required management techniques to guarantee quality and timely delivery.

- The company would provide the necessary specification translations to ensure that the product conformed to the original design, and then contract the manufacturing service, taking into account cost and delivery lead times, including shipping.

- $\quad$ Breaking down the complete design, and contracting the manufacturing process of sub-components to various smaller companies with the technology to build the tool components, the businesses would not require a large amount of working capital.

- With a higher throughput of tools, the company would assemble the subcomponents into the final tool, and would be able to use the equipment needed in the final product manufacturing process to conduct the final tool test.

- With an in-depth understanding of tool design and construction, the company would be able to employ local technicians to conduct the necessary after-sales maintenance and repair services. 
The dominant isolating mechanisms that would protect the business strategy from being undermined by imitation by competitors or disintermediation by customers include:

- Access to and relationship with the German design partners

- Supply of material at competitive prices

- Global network of qualified tool suppliers

- $\quad$ Small working capital capacity

- $\quad$ Relationship of trust developed with customers over time

\subsection{Q4 - Growth and implementation}

In order to convert the analysis and business model into action, the E-PERA tool has guided the business model to define, among other things, the necessary IT and visual management systems to facilitate communication and project management. A financial roadmap - which dictated how funds would be raised to increasingly absorb the outsourced functions and thus facilitate growth - was compiled with the first round of shareholder fundraising underway .

At the time of writing this paper, the customer had bought into the resulting business model on paper, and the implementation of the business model was in process.

\section{CONCLUSION}

As discussed in section 3.1, the maj or strategic models and frameworks have the ability to explain a company's competitive advantage at a single point in time. However, they neglect to detail the processes involved in developing the strategy and subsequently achieving success.

The SVA framework, as a live product that should constantly evolve, addresses the shortcomings of current strategic models in the context of SMEs, in that it:

- $\quad$ takes into account the specific characteristics of SMEs;

- $\quad$ guides the user through detailed processes to formulate a strategy and business model; and

- it is not specific to an industry or sector.

The framework allows SMEs to address their specific shortcomings through a combination of risk-mitigating factors or actions in order to align their strategic intent and business model with VC demands, allowing them to gain access to the necessary funding to grow their business and leverage off the non-financial resources of the VC companies.

Ultimately the framework unites management and investors behind a unified vision, provides motivation in the form of strategic intent, and installs the necessary communication and project management infrastructure to ensure plans are translated into action.

Future research that might arise from this framework includes the use of specific tools in specific types of industries. The framework will ultimately be tested to see whether it would fall into the category of SMEs that are successful after the first two years.

\section{REFERENCES}

[1] Pasanen, M. 2006. SME growth strategies: A comparison of young and long-lived firms. Paper presented at the International Conference on Business and Information, Academy of Taiwan Information Systems Research, Singapore

[2] Majumbar, S. 2008. Modelling growth strategy in small entrepreneurial business organisations. Journal of Entrepreneurship, 17(2), pp. 157-168.

[3] Matthews, C.H. \& Scott, S.G. 1995. Uncertainty and planning in small and entrepreneurial firms: An empirical assessment. J ournal of Small Business Management, 33(4), pp. 34-52.

[4] Ayyagari, M., Beck, T. \& Demirguc-Kunt, A. 2003. Small and medium enterprises across the globe: A new database. No. 3127. World Bank Policy Research Working Paper. 
[5] Von Broemsem, M,, Wood, M. \& Herrington, M. 2005. Global entrepreneurship monitor. www. gemconsortium.org.

[6] Snyman, H.A., Kennon, D., Schutte, C.S. \& von Leipzig, K. 2013. Formulating a strategic framework to promote SME development. Stellenbosch, SAllE25 Conference, 2013.

[7] Smith, A. 1776. Wealth of nations. Bantam Classics.

[8] Ricardo, D. 1821. On the principles of political economy and taxation. London: J ohn Murray.

[9] Wennekers, S. \& Thurik, R. 1999. Linking entrepreneurship and economic growth. Small Business Economics, Volume 13, pp. 27-55.

[10] Audretsch, D.B. \& Thurik, A.R. 1999. Capitalism and democracy in the 21st century: From the managed to the entrepreneurial economy. J ournal of Evolutionary Economics, Vol 10, pp. 17-34.

[11] Bosma, N., Acs, Z. \& Autio, E. 2008. Global entrepreneurship monitor. Global Entrepreneurship Research Consortium (GERA).

[12] Drucker, P.F. 1985. The practice of innovation. New York: Harper \& Row.

[13] Glaeser, E.L., La Porta, R., de Silanes, F.L. \& Shleifer, A. 2004. Do institutions cause growth? J ournal of Economic Growth, Volume 9, pp. 271-303.

[14] North, D.N., Summerhill, W. \& Weingast, B.R. 2000. Order, disorder and economic change: Latin America vs. North America. In Bruce Bueno de Mesquita and Hilton Root, eds, Governing for prosperity, pp. 17-58.

[15] Rosenberg, N. \& Birdzell J r., L.E. 1986. How the West grew rich: The economic transformation of the industrial world. Basic Books.

[16] Lumpkin, G.T. \& Dess, G.G. 2001. Linking two dimensions of entrepreneurial orientation to performance: The moderating role of environment and industry life cycle. J ournal of Business Venturing, 16(5), pp. 429-451.

[17] Carlsson, B. 1999. Small business, entrepreneurship and industrial dynamics. Boston: Kluwer Academic Publishers.

[18] Reynolds, P.D. 2000. National panel study of U.S. business start-ups: Background and methodology. Advances in Entrepreneurship, Firm Emergence, and Growth, Volume 4, pp. 153227.

[19] Storey, D. 1994. Understanding the small business sector. London: Routledge.

[20] Clark, D., Berkely, N. \& Steuer, N. 2001. Attitudes to growth among owners of small and medium-sized enterprises and the implications for business advice. International Small Business J ournal, 19(3), pp. 72-77.

[21] Wiklund, J., Patzelt, H. \& Shepherd, D. 2007. Building an integrative model of small business growth. Small Business Economics, Volume 32, pp. 351-374.

[22] Madsen, L. 2007. The significance of sustained entrepreneurial orientation on performance of firms - A longitudinal analysis. Entrepreneurship and Regional Development, Volume 19, pp. 185204.

[23] Storey, D. 1997. The ten percenters. Deloitte \& Touche

[24] Connor, K. 1991. A historical comparison of resource based theory and five schools of thought within industrial organisation economics. J ournal of Management, Volume 17, pp. 121-154.

[25] Wiklund, J. \& Shepherd, D. 2003. Aspiring for, and achieving growth: The moderating role of resources and opportunities. J ournal of Management Studies, 40(8), pp. 1919-1945

[26] Weinzimmer, L.G., Nystrom, P.C. \& Freeman, S.J. 1998. Measuring organizational growth: Issues, consequences and guidelines. J ournal of Management, 24(2), pp. 235-262.

[27] Mintzberg, H., Alstrand, B. \& Lampel, J . 2009. Strategic safari: Your complete guide through the wilds of strategic management. Great Britain: Prentice Hall.

[28] Hrebiniak, L.G. \& J oyce, W.F. 1985. Organiszational adaptation: Strategic choice and environmental determinism. Administrative Science Quarterly, Volume 30, pp. 336-349

[29] Schwartz, P. 1991. The art of the long view. Doubleday Business.

[30] Sunter, C. \& Illbury, C. 2001. The mind of a fox: Scenario planning in action. Human \& Rousseau.

[31] Grant, R.M. 2008. Contemporary strategy analysis. Blackwell Publishers, 6th edition.

[32] Porter, M.E. 1987. From competitive advantage to corporate strategy. Harvard Business Review, 65(3), pp. 43-59.

[33] Klinke, A. \& Renn, 0. 2004. Precautionary principle and discursive strategies: Classifying and managing risks. J ournal of Risk Research, 4(2), pp. 159-173.

[34] de Neufville, R. 2004. Uncertainty management for engineering systems planning and design. Engineering Systems Monograph

[35] Marais, S.J . \& Schutte, C.S.L. 2009. The definition and development of open innovation models to assist the innovation process. Conference Article For SAlIE 2009.

[36] West, J \& \& Gallagher, S. 2006. Challenges of open innovation: The paradox of firm investment in open-source software. R\&D Management, 36(3), pp. 319-331.

[37] Kim, W.C. \& Mauborgne, R. 2005. Blue ocean strategy. Harvard Business School Press

[38] Teece, J. 2010. Business models, business strategy and innovation. Long Range Planning, Volume 43, pp. 172-194. 
[39] Arbaugh, J.B. \& Camp, S.M. 2000. Managing growth transitions: Theoretical perspectives and research directions. Oxford: Blackwell.

[40] Dsouza, D. 1990. Strategy types and environmental correlates of strategy for high-growth firms: An exploratory study. Georgia State University.

[41] Burns, P. 1989. Strategies for success and routes to failure, in small business and entrepreneurship. Basingstoke: MacMillan.

[42] Thompson, J . 2001. Strategic management. London: Thomson Learning.

[43] Nooteboom, B. 2000. Learning and innovation in organizations and economies. Oxford: Oxford University Press.

[44] Changati, R. 1987. Small business strategies in different industry growth environments. J ournal of small business management, 25(3), pp. 60-68.

[45] Nooteboom, B. 2002. Entrepreneurship: Critical perspectives on business management. Morris F. Krueger Edition. London and New York: Routledge.

[46] Thomson J r., A.A. \& Strickland III, A.J. 1999. Strategic management - Concepts and cases. Singapore: Irwin McGraw-Hill.

[47] Hamel, G. \& Prahalad, C.K. 2002. Competing for the future. New Delhi: Tata McGraw-Hill.

[48] Bhide, A. 1994. How entrepreneurs craft strategies that work. Harvard Business Review, March April 1994.

[49] McMohan, R.G.P. 2001. Growth and performance of manufacturing SMEs: The Influence of financial management characteristics. International Small Business J ournal, 19(3), pp. 10-28.

[50] Gockel, A.F. \& Akoena, S.K. 2002. Financial intermediation for the poor: Micro, small and medium scale enterprises in ghana - a further assignment for financial sector policy? IFLIP, 2(6).

[51] Kirzner, I. 1985. Discovery and the capitalist process. Chicage and London: University of Chicago Press.

[52] Martin, G. \& Staines, H. 2008. Managerial competencies in small firms. [Online] Available at: http:// www.emeraldinsight.com/ doi/ abs/ 10.1108/02621719410063396 [Accessed March 20 2013].

[53] Kayanula, D. \& Quartey, P. 2000. The policy environment for promoting small and medium-sized enterprises in Ghana and Malawi. Finance and Development Research Programme, Volume 15.

[54] Okten, G. \& Osil, U. 2004. Social networks and credit access in Indonesia. World Development, 37(2), pp. 1225-1246.

[55] Shane, S. \& Cable, D. 2002. Network ties, reputation and the financing of new ventures. Management Science, 48(3), pp. 364-381.

[56] Ngoc, T., Le, T. \& Nguyen, T. 2009. The impact of networking on bank financing: The case of small and medium enterprises in Vietnam. Entrepreneurship Theory and Practice, 33(4), pp. 867887.

[57] Phillips, P. \& Wade, M. 2008. Performance implications of capital structure. Hotel Interest Service Industries J ournal, 24(5), pp. 31-51.

[58] Smallbone, D., Leig, R. \& North, D. 2003. The characteristics and strategies of high growth SMEs. [Online] Available at: www.emeraldinsight.com [Accessed March 16 2013].

[59] Lader, P. 1996. The public/ private partnership Springs. Spring, 35(2), pp. 41-44.

[60] Cassar, G. 2004. Entrepreneur motivation, growth intentions and preferences. Frontiers of Entrepreneurship Research, Volume 19, pp. 422-435.

[61] Cook, P. \& Nixson, F. 2000. Finance and small and medium sized enterprise development. Finance and Development Research Program Working Paper Series, Volume 14.

[62] Dickinson, T. 2007. Private equity: Helping fill Africa's financing gap. OECD.

[63] CFA Institute, 2010. CFA Level I. CFA Institute.

[64] Meyer, T. \& Mathonet, P.-Y. 2008. J -Curve exposure: Managing a portfolio of venture capital and private equity funds. J ohn Wiley $\&$ Sons, Ltd.

[65] Cui, Y., Zha, L. \& Zhang, F. 2010. Financial support system and strategy of SMEs in the incubation based on business life cycle. International Business Research, 3(4), pp. 119-122.

[66] Snyman, H. 2012. Economic growth, entrepreneurship and venture capital in South Africa, Cape Town: University of Cape Town.

[67] National Treasury of South Africa, s.j. Old Mutual. [Online] Available at: http:/ / www. oldmutual.co.za/ documents/ omigsa/ Regulation28ofthePensionFundsAct. pdf. [Accessed 15 February 2013].

[68] Zackarakis, A. \& Meyer, G.D. 1998. A lack of insight: Do venture capitalists really understand their own? J ournal of Business Venturing, 13(1), pp. 57-76.

[69] Hsu, M. 2007. Experienced entrepreneurial founders, organizational capital and venture capital funding. Research Policy, 36(5), pp. 722-741.

[70] Engel, D. \& Keilbach, M. 2007. Firm-level implications of early stage venture capital investment - An empirical investigation. J ournal of Empirical Finance, Elsevier, 14(2), pp. 150-167.

[71] Brush, C.G., Edelman, L.F. \& Manolova, T.S. 2012. Ready for funding? Entrepreneurial ventures and the pursuit of angel financing. Venture Capital, 14(2-3), pp. 111-129.

[72] Sudek, R. 2006. Angel investment criteria. J ournal of Small Business Strategy, 17(2), pp. 89-103. 
[73] Wiltbank, R., Read, S., Dew, N. \& Sarasvathy, S.D. 2009. Prediction and control under uncertainty: Outcomes in angel investing. J ournal of Business Ventureing, Volume 24, pp. 116133.

[74] Miloud, T., Aspelund, A. \& Cabrol, M. 2012. Startup valuation by venture capitalists: An empirical study. Venture Capital, April-J uly, 14(2-3), pp. 151-174.

[75] Dimov, D. \& Shepherd, D. 2005. Human capital theory and venture capital firms: Exploring 'home runs' and 'strike outs'. J ournal of Business Venturing, Volume 20, pp. 1-21.

[76] St-Pierre, J., Nomo, T.S. \& Pilaeva, K. 2011. The non-financial contribution of venture capitalists to VC-backed SMEs: The case of traditional sectors. Venture Capital, April, 13(2), pp. 103-118.

[77] Bruton, G.D., Fried, F. \& Manigart, S. 2005. Institutional influences on the worldwide expansion of venture capital. Entrepreneurship Theory and Practice, 29(6), pp. 737-760.

[78] Kaplan, R.S. \& Norton, D.P. 2004. Measuring the strategic readiness of intangible assets. Harvard Business Review, February, pp. 52-63.

[79] Porter, M. 1991. Towards a dynamic theory of strategy. Strategic Management J ournal, Volume 12, pp. 95-117.

[80] Kennon, D. 2010. Improbable circumstances strategic framework. Master's Thesis, University of Stellenbosch.

[81] du Preez, N.D. \& Reid, J.M.C. 1998. Integrated product and enterprise design for global competitiveness. South African J ournal of Industrial Engineering, 9(1), pp. 37-45.

[82] National Tooling Initiative. 2012. The National Tooling Initiative Handbook. Tooling Association of South Africa.

[83] Laukkanen, M. 1999. In search of entrepreneurship and new ventures: Local development strategies in a global environment. Kuopio University Press. 